\title{
RICE PARBOILING WASTEWATER IN THE MAXIMIZATION OF CAROTENOIDS BIOPRODUCTION BY Phaffia rhodozyma
}

\author{
Água de parboilização do arroz na maximização da bioprodução de \\ carotenoides por Phaffia rhodozyma
}

\author{
Danielle Alves da Silva Rios ${ }^{1}$, Thais de Matos de Borba ${ }^{1}$, \\ Susana Juliano Kalil ${ }^{1}$, Janaína Fernandes de Medeiros Burkert ${ }^{2}$
}

\begin{abstract}
The interest in carotenoid production from natural sources has increased based in their possible use as dyes and their powerful biological antioxidant capacity. This study evaluated the use of rice parboiling wastewater (RPW) as an alternative substrate for the bioproduction of carotenoids using the yeast Phaffia rhodozyma and found it to be promising as the only source of nutrients, reaching a concentration of $0.6 \mu \mathrm{g} \mathrm{mL}^{-1}\left(259.1 \mu \mathrm{g} \mathrm{g}^{-1}\right)$ in $48 \mathrm{~h}$. To increase the potential use of this industrial effluent, a study of supplementation was carried out to enhance the production of carotenoids using the methodology of experimental design (a $2_{\text {IV }}{ }^{6-2}$ fractional factorial design sequenced by a $2^{4}$ central composite design). The conditions for maximizing the production of carotenoids were $\left(\mathrm{g} \mathrm{L}^{-1}\right)$ malt extract (16.25), peptone (8.75), sucrose (15) and rice parboiling wastewater (87.5), with a $\mathrm{pH}$ of 5 at $25^{\circ} \mathrm{C}$ and $150 \mathrm{rpm}$ for $144 \mathrm{~h}$, which produced a concentration $5.3 \mu \mathrm{g} \mathrm{mL}^{-1}\left(628.8 \mu \mathrm{g} \mathrm{g}^{-1}\right)$.
\end{abstract}

Index terms: Biodye; submerged cultive; response surface methodology; yeast.

\section{RESUMO}

O interesse pela produção de carotenoides por fontes naturais é crescente, em decorrência da possibilidade de atuar como corante e sua capacidade antioxidante biológica potente. Neste estudo, avaliou-se o uso da água de parboilização do arroz, como substrato alternativo para a bioprodução de carotenoides, usando a levedura Phaffia rhodozyma que, como única fonte de nutrientes, foi promissora, alcançando $0,6 \mu \mathrm{g} \mathrm{mL}^{-1}\left(259,1 \mu \mathrm{g} \mathrm{g}^{-1}\right)$ em $48 \mathrm{~h}$. Para aumentar o potencial de aproveitamento desse efluente industrial, um estudo da suplementação do meio de produção foi realizado para incrementar a obtenção dos carotenoides, utilizando a metodologia do planejamento fatorial (um planejamento fatorial $2_{\mathrm{IV}}{ }^{6-2}$ sequenciado por um planejamento fatorial completo $2^{4}$ ). As condições maximizadas de produção de carotenoides foram $\left(\mathrm{g} \mathrm{L}^{-1}\right)$ : extrato de malte, 16,25; peptona, 15 e água de parboilização de arroz, 87,5, com pH 5, a $25^{\circ} \mathrm{C}, 150 \mathrm{rpm}$ por $144 \mathrm{~h}$, alcançando $5,3 \mu \mathrm{g} \mathrm{mL}-1\left(628,8 \mu \mathrm{g} \mathrm{g}^{-1}\right)$.

Termos para indexação: Biocorantes; cultivo submerso; superfície de resposta; levedura.

\section{INTRODUCTION}

Rice is one of the most important cereals in the world and is the main component of the Brazilian diet. Brazil is among the 10 largest producers of rice, and the process of parboiling is one of the most important methods of preparation. This process involves a significant use of water, on average up to $4 \mathrm{~m}^{3} \mathrm{ton}^{-1}$ of processed grain, which results in a considerable volume of effluent (Zepka et al., 2008). The main components of this effluent are nitrogen and organic matter, which suggests the possibility of their use as an alternative nutrient source for the production of high value products (Queiroz et al., 2007). Among these, astaxanthin, an oxygenated carotenoid that has a typical orange-pink color, is widely distributed in nature, presenting biological functions that have attracted increasing interest. The largest source of this carotenoid is the alga Haematococcus pluvialis, but it can also be produced by various yeasts, being the main carotenoid synthesized by the yeast Xanthophyllomyces dendrorhous, popularly known as Phaffia rhodozyma (Domínguez-Bocanegra; Ponce-Noyola; Torres-Muñoz, 2007; Rodriguez-Saiz; Fuente; Barredo, 2010).

Because of concern about the use of chemical additives in food, there is increasing interest in carotenoids obtained naturally by biotechnological processes (Valduga et al., 2011). The global market demand for carotenoids grows by $2.9 \%$ per year (Gu et al., 2008; Valduga et al., 2011) and is expected to reach almost 10 million tons by 2017 (Venil; Zakaria; Ahmad, 2013).

A significant increase in carotenoid production by various microorganisms has been observed with the use of the methodology of factorial design to evaluate different means of production, culture conditions, such

${ }^{1}$ Universidade Federal do Rio Grande/FURG - Rio Grande - RS - Brasil

2Universidade Federal do Rio Grande/FURG - Cx. P. 474 - 96201-900 - Rio Grande - RS - Brasil - jfmb@vetorial.net

Received in march 6, 2015 and approved in april 27, 2015 
as $\mathrm{pH}$, temperature, aeration, and inoculum concentration, and recovery of these compounds (Ni et al., 2007; Liu; $\mathrm{Wu}, 2007$; Gu et al., 2008; Ni et al., 2008; Valduga et al., 2011; Cabral et al., 2011; Michelon et al., 2012). In previous work conducted by our research group, the use of a culture medium containing rice parboiling wastewater (15 $\left.\mathrm{g} \mathrm{L}^{-1}\right)$ supplemented with other sources of nutrients for the production of carotenoids from $P$. rhodozyma NRRL Y-17268 was investigated (Silva et al., 2012).

Within this context, the objective of this study was to use rice parboiling wastewater (RPW) as an alternative source of nutrients for $P$. rhodozyma to maximize the production of carotenoids, establishing the conditions of a medium culture.

\section{MATERIAL AND METHODS}

\section{Partial characterization of culture medium components}

The RPW was provided by a rice milling plant in the city of Pelotas, Brazil. It was centrifuged at 1870xg for $10 \mathrm{~min}$ for particle removal. A partial RPW and yeast malt (YM) medium characterization was performed, and concentrations of carbon $(\mathrm{C})$ and hydrogen $(\mathrm{H})$ were determined using a CHNS/O analyzer (Perkin Elmer, 2400 , Germany). For equipment calibration, the certified reference material acetanilide was used to provide quality control for the determinations. Nitrogen (N) determination was carried out using the Kjeldahl method (AOAC, 2000). The concentration of non-reducing sugars was determined using the DNS method (Miller, 1959), and phosphorus and soluble solid contents were also analyzed (AOAC, 2000).

\section{Microorganism}

The yeast $P$. rhodozyma NRRL Y-17268 was used for the production of carotenoids. It was provided by the Northern Regional Research Laboratory (Peoria, IL, USA) and is certified as GRAS (Generally Recognized as Safe). Before the experiments, the yeast was suspended in YM broth containing $\left(\mathrm{g} \mathrm{L}^{-1}\right)$ yeast extract (3), malt extract (3), peptone (5) and glucose (10), incubated at $25^{\circ} \mathrm{C}$ for $48 \mathrm{~h}$ and then maintained in glycerol $(10 \%)$ at $-18^{\circ} \mathrm{C}$ (Silva et al., 2012).

\section{Inoculum}

The inoculum was prepared by adding $10 \mathrm{~mL}$ of culture in glycerol to $500 \mathrm{~mL}$ Erlenmeyer flasks containing $153 \mathrm{~mL}$ of culture medium (YM) supplemented with $0.2 \mathrm{~g} \mathrm{~L}^{-1} \mathrm{KNO}_{3}$ previously sterilized in an autoclave at $121^{\circ} \mathrm{C}$ for $15 \mathrm{~min}$. The suspension was maintained for $48 \mathrm{~h}$ at $25^{\circ} \mathrm{C}$ in a rotary incubator at $150 \mathrm{rpm}$, and growth was monitored by counting in a Neubauer chamber (Michelon et al., 2012).

\section{Shaken flask cultivation}

P. rhodozyma NRRL Y-17268 was cultivated in $500 \mathrm{~mL}$ Erlenmeyer flasks (153 mL culture medium) that were sterilized in an autoclave at $121{ }^{\circ} \mathrm{C}$ for $15 \mathrm{~min}$. Each flask was inoculated with a $10 \%$ solution of the yeast suspension previously prepared to achieve $1 \times 10^{7}$ cells $\mathrm{mL}^{-1}$ at the beginning of cultivation. The flasks were maintained in an incubator at $25^{\circ} \mathrm{C}$ and $150 \mathrm{rpm}$ for $168 \mathrm{~h}$. Culture samples were collected to determine the $\mathrm{pH}$, biomass concentration and the specific and volumetric production of carotenoids every $24 \mathrm{~h}$.

\section{Experimental design and statistical analysis}

The initial cultivations were performed in triplicate $(n=3)$ to evaluate RPW as the sole source of nutrients in the production of carotenoids. Sequential concentrations of the culture medium were established according to two factorial designs. In the first $2_{\text {IV }}{ }^{6-2}$ fractional factorial design (Table 1), the effects of the concentrations of six variables in carotenoid production were studied. A culture medium containing $\left(\mathrm{g} \mathrm{L}^{-1}\right)$ malt extract (5), peptone (5), sucrose (10) and RPW (90) with an initial $\mathrm{pH}$ of 5 was used to evaluate the concentration of yeast extract $\left(0.0,0.5\right.$ and $\left.1.0 \mathrm{~g} \mathrm{~L}^{-1}\right)$. The results were evaluated by analysis of variance (ANOVA) and Tukey's test $(\mathrm{p}<0.05)$. A central composite design $\left(\mathrm{CCD} 2^{4}\right)$ with three replicates $(\mathrm{n}=3)$ at the central point was used to study the four variables selected from the fractional design. The responses evaluated were maximum biomass concentration and the specific and volumetric production of carotenoids in each trial. The results were evaluated using Statistica 5.0 software (Statsoft, Inc., Tulsa, OK, USA).

\section{pH determination}

The pH of the cultures was measured potentiometrically by a $\mathrm{pH}$ meter (Marte, MB-10, Brazil) (AOAC, 2000).

\section{Biomass concentration}

The optical density of the sample (properly diluted) was measured using a spectrophotometer (at $620 \mathrm{~nm}$ ) to determine the biomass concentration. The optical density was related to the cell dry weight using an experimentally determined calibration curve (Kusdiyantini et al., 1998). 
Table 1: Levels and concentrations of the variables studied at the factorial designs.

\begin{tabular}{cccc}
\hline Variables & $\begin{array}{c}\text { Level }-1 \\
\left(\mathrm{~g} \mathrm{~L}^{-1}\right)\end{array}$ & $\begin{array}{c}\text { Level 0 } \\
\left(\mathrm{g} \mathrm{L}^{-1}\right)\end{array}$ & $\begin{array}{c}\text { Level +1 } \\
\left(\mathrm{g} \mathrm{L}^{-1}\right)\end{array}$ \\
\cline { 2 - 4 } Yeast Extract & \multicolumn{2}{c}{$2_{\mathrm{IV}}{ }^{6-2}$ fractional factorial } \\
Malt Extract & 1 & 5.5 & 10 \\
Peptone & 1 & 5.5 & 10 \\
Sucrose & 5 & 5.5 & 10 \\
RPW $^{*}$ & 0 & 12.5 & 20 \\
pH & 4 & 90 & 180 \\
& \multicolumn{4}{c}{5} \\
Malt Extract & 8.75 & 12.5 & 6 \\
Peptone & 8.75 & 12.5 & 16.25 \\
Sucrose & 15 & 25 & 35 \\
RPW* & 87.5 & 125 & 162.5 \\
\hline *RPW (rice parboiling wastewater).
\end{tabular}

\section{Extraction and determination of total carotenoids}

The extraction of total carotenoids was carried out by using $0.05 \mathrm{~g}$ of dry cells $\left(35^{\circ} \mathrm{C}\right.$ for $\left.48 \mathrm{~h}\right)$ and, after freezing $\left(-18{ }^{\circ} \mathrm{C}\right.$ for $48 \mathrm{~h}$ ), adding $2 \mathrm{~mL}$ of dimethyl sulfoxide for cell disruption according to Fonseca et al. (2011). After cell disruption, the carotenoids were extracted by adding $10 \mathrm{~mL}$ of acetone. Then, the samples were centrifuged (Centribio $80-2 \mathrm{~B}$, Brazil) at $1870 \mathrm{xg}$ for $10 \mathrm{~min}$. The supernatant was separated, and successive extractions were carried out until both the solvent and cells were colorless. Next, $10 \mathrm{~mL}$ of $20 \%$ (w/v) $\mathrm{NaCl}$ solution and $10 \mathrm{~mL}$ of petroleum ether were added. After agitation and phase separation, the excess water was removed with anhydrous sodium sulfate $\left(\mathrm{Na}_{2} \mathrm{SO}_{4}\right)$. The total carotenoids in the extracts were measured by a spectrophotometer (BIOSPECTRO SP-220) at $474 \mathrm{~nm}$ and quantified (Equation 1) using the specific absorptivity coefficient of 1600 for xanthophylls (Domínguez-
Bocanegra; Ponce-Noyola; Torres-Muñoz, 2007; Ni et al., 2008).

$$
\text { S.P.C }=\left(10^{6} A V\right) /(100 \times 1600 W)
$$

where S.P.C. is the specific production of carotenoids ( $\mu \mathrm{g}$ $\left.\mathrm{g}^{-1}\right)$; $\mathrm{A}$ is the absorbance; $\mathrm{V}$ is the volume $(\mathrm{mL})$ of acetone (filtrate); and $\mathrm{W}$ is the dry cell mass (g).

The carotenoid volumetric concentration (VPC, $\mu \mathrm{g}$ $\left.\mathrm{mL}^{-1}\right)$ was determined by converting the results of the SPC $\left(\mu \mathrm{g} \mathrm{g}^{-1}\right)$ and the biomass concentration $\left(\mathrm{g} \mathrm{L}^{-1}\right)$.

\section{RESULTS AND DISCUSSION}

\section{Partial characterization of substrates of culture media}

The partial characterization of the substrates of the culture media is described in Table 2, where the total nitrogen and phosphorus concentrations of the rice parboiling wastewater comply with the literature on this agro-industrial residue (Queiroz et al., 2007; Silva et al., 2012). Therefore, the quantities of nitrogen and phosphorus of the RPW turn these materials into potential sources for such nutrients in the culture medium.

\section{Cultivation with rice parboiling wastewater}

According to Figure 1, there was a promising production of carotenoids by $P$. rhodozyma using only RPW as a source of nutrients. In RPW, the yeast synthesized carotenoids in the cells, reaching a maximum specific carotenoids production of $259.1 \mu \mathrm{g} \mathrm{g}^{-1}$ and a volumetric carotenoids production of $0.6 \mu \mathrm{g} \mathrm{mL}^{-1}$ in $48 \mathrm{~h}$. The variation in the production of specific carotenoids most likely occurs due to the simultaneous synthesis of other carotenoids that interferes in the evaluation of the specific wavelength necessary for the measurement of a particular carotenoid (An; Cho; Johnson, 1999).

Table 2: Partial characterization of substrates of culture media.

\begin{tabular}{ccccccc}
\hline Substrates & Carbon (\%) & Hydrogen (\%) & Nitrogen $(\%)$ & $\begin{array}{c}\text { Total sugars } \\
\left(\mathrm{mg} \mathrm{L}^{-1}\right)\end{array}$ & $\begin{array}{c}\text { Total soluble } \\
\text { solids }\left(\mathrm{g} \mathrm{L}^{-1}\right)\end{array}$ & $\begin{array}{c}\text { Phosphorus } \\
\left(\mathrm{mg} \mathrm{L}^{-1}\right)\end{array}$ \\
\hline Yeast extract & 38.40 & 5.65 & 10.67 & $\mathrm{ND}$ & $\mathrm{ND}$ & $\mathrm{ND}$ \\
Malt extract & 39.24 & 6.54 & 10.93 & $\mathrm{ND}$ & $\mathrm{ND}$ & $\mathrm{ND}$ \\
Peptone & 43.47 & 6.71 & 14.47 & $\mathrm{ND}$ & $\mathrm{ND}$ & $\mathrm{ND}$ \\
$\mathrm{RPW}^{*}$ & 0.16 & 2.25 & 3.02 & 67.0 & 3.97 & 30.7 \\
\hline
\end{tabular}

*RPW (rice parboiling wastewater); ND (not determined). 


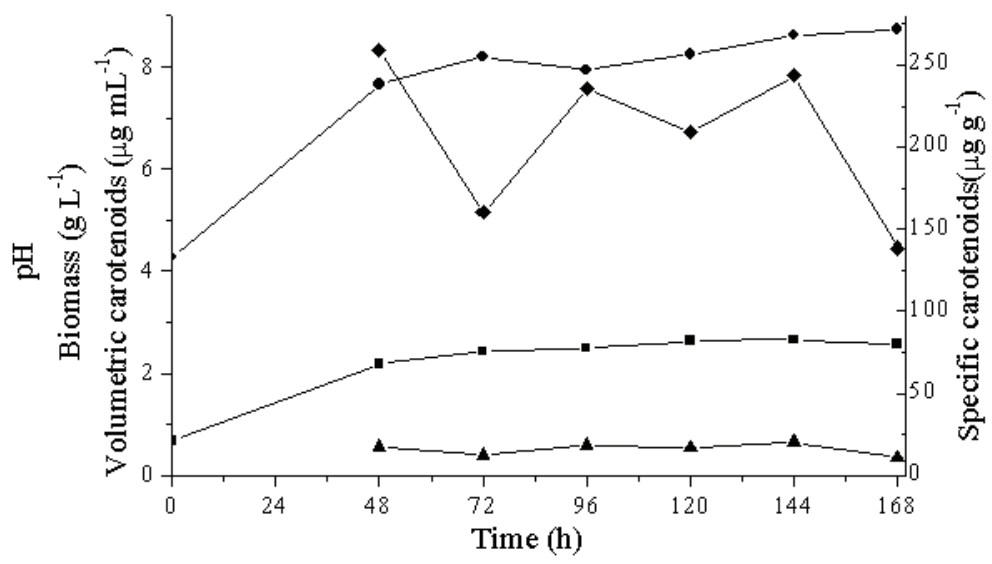

Figure 1: Cultivation with rice parboiling wastewater ( $\bullet$ biomass, $\bullet \mathrm{pH}, \boldsymbol{\Delta}$ volumetric carotenoids, $\bullet$ specific carotenoids) at $25^{\circ} \mathrm{C}$ and $150 \mathrm{rpm}(\mathrm{n}=3)$.

The maximum biomass concentration reached in the RPW was $2.7 \mathrm{~g} \mathrm{~L}^{-1}$ in $48 \mathrm{~h}$ (Figure 1), lower than that obtained by Silva et al. 2012 using the same yeast in a RPW culture medium supplemented with other sources of nutrients. This behavior is most likely associated with the composition of the culture medium, specifically the ratio of carbon to nitrogen $(\mathrm{C}: \mathrm{N})$, which was very low in the RPW medium $(\mathrm{C}: \mathrm{N}=0.05)$. According to Vustin, Belykh and Kishilova (2004), a C:N ratio less than 5 may influence the synthesis of carotenoids by P. rhodozyma in a negative way, whereas higher ratios indicate a smaller concentration of nitrogen in the culture medium, which causes a large reduction in biomass growth and thereby in the volumetric production of carotenoids. The alga $H$. pluvialis responded similar to the observations of this work, with nitrogen limitation in the medium culture resulting in the reduction of primary metabolism (synthesis of protein and chlorophyll) and affecting the secondary metabolism and biosynthesis of astaxanthin (Ip; Chen, 2005). However, the $\mathrm{C}: \mathrm{N}$ ratio alone cannot explain the growth and carotenoid production, as other nutrients such as vitamins, amino acids and minerals as well as the types of carbon and nitrogen sources have a stronger influence on the metabolism of yeasts (Vustin; Belykh; Kishilova, 2004; Dominguez-Bocanegra et al., 2007; Ni et al., 2008).

Therefore, to increase the biomass concentration and consequently the volumetric production of carotenoids, the next step of this work was to use rice parboiling wastewater supplemented with other nutrients such as yeast extract, malt extract, peptone and sucrose. For this purpose, experimental design was used to determine an association between these nutrients and the rice parboiling wastewater to enable the joint maximization of the bioproduction of carotenoids and reduction in costs of the production medium.

\section{Fractional factorial design}

In the $2_{\text {IV }}^{6-2}$ fractional factorial design (data not shown), the biomass and the productions of total carotenoids were determined every $24 \mathrm{~h}$ for $168 \mathrm{~h}$. The biomass concentration ranged from 1.8 (trial 1 in $24 \mathrm{~h}$ ) to $8.1 \mathrm{~g} \mathrm{~L}^{-1}$ (trial $15 \mathrm{in} 168 \mathrm{~h}$ ), the volumetric production of carotenoids from 0.4 (trial 1 in $120 \mathrm{~h}$ ) to $3.1 \mu \mathrm{g} \mathrm{mL}^{-1}$ (trial 15 in $168 \mathrm{~h}$ ) and the specific production of carotenoids from 240.3 (trial 1 in $24 \mathrm{~h}$ ) to $538.4 \mu \mathrm{g} \mathrm{g}^{-1}$ (trial 6 in $144 \mathrm{~h})$.

The estimates of the main effects were determined according to Rodrigues and Iemma, 2012. Asshown in Figure2, an increase in the concentration of yeast extract from level -1 $\left(1 \mathrm{~g} \mathrm{~L}^{-1}\right)$ to level $+1\left(10 \mathrm{~g} \mathrm{~L}^{-1}\right)$ was not statistically significant $(p>0.1)$ for any response. However, the concentrations of malt extract and peptone within the same concentration range as the previous variable showed a significant effect $(\mathrm{p}<0.1)$, increasing the concentration of biomass $\left(1.7 \mathrm{~g} \mathrm{~L}^{-1}\right.$ and $0.5 \mathrm{~g} \mathrm{~L}^{-1}$, respectively) and the volumetric production of carotenoids $\left(0.7 \mu \mathrm{g} \mathrm{mL}^{-1}\right.$ and $0.3 \mu \mathrm{g} \mathrm{mL}^{-1}$, respectively). The increased production of specific carotenoids was significant $(p<0.1)$ only concentration of peptone with an increased of $33.2 \mu \mathrm{g} \mathrm{g}^{-1}$.

Behavior similar to that observed in this work, with no significant influence of the presence of yeast extract together with other sources of nitrogen on the production of carotenoids, were observed with different strains of Phaffia rhodozyma (Ni et al., 2007, Liu; Wu, 2007), the 
presence of yeast extract together with other sources of nitrogen have been screened out as non-significant factors of both the cell growth rate and carotenoid biosynthesis of $P$. rhodozyma in shake-flask cultures.

An increase in the sucrose concentration from 5 to $20 \mathrm{~g} \mathrm{~L}^{-1}$ showed the greatest influence and most significant effect of all of the variables. This effect was positive for biomass and volumetric production, increasing by $2.8 \mathrm{~g} \mathrm{~L}^{-1}$ and $0.8 \mu \mathrm{g} \mathrm{mL}^{-1}$, respectively. However, the effect was negative for specific production, decreasing by $71.4 \mu \mathrm{g} \mathrm{g}^{-1}$ (Figure 2). High concentrations of carbon sources can inhibit the synthesis of carotenoids (Vustin; Belykh; Kishilova, 2004), as verified in this study and observed by Liu and $\mathrm{Wu}$ (2007). A similar effect was observed upon increasing the glucose concentration from 15 to $40 \mathrm{~g} \mathrm{~L}^{-1}$, which increased the biomass by $3.3 \mathrm{~g} \mathrm{~L}^{-1}$ and decreased the production of carotenoids by $917 \mu \mathrm{g} \mathrm{g}^{-1}$.

A significant increase of $0.6 \mathrm{~g} \mathrm{~L}^{-1}$ in biomass concentration was observed when the RPW concentration increased from $0 \mathrm{~g} \mathrm{~L}^{-1}$ (level -1) to $180 \mathrm{~g} \mathrm{~L}^{-1}$ (level +1). Moreover, RPW is an excellent source of organic nitrogen (Queiroz et al., 2007) and may preferentially utilized by the yeast, replacing yeast extract. However, the opposite effect was found for the production of carotenoids, which experienced decreases of $57.4 \mu \mathrm{g} \mathrm{g}^{-1}$ and $0.1 \mu \mathrm{g} \mathrm{mL}^{-1}$ (Figure 2).

The $\mathrm{pH}$ presented a positive effect on specific production, increasing by $27.8 \mu \mathrm{g} \mathrm{g}^{-1}$, a negative effect on volumetric production, decreasing by $0.2 \mu \mathrm{g} \mathrm{mL} \mathrm{L}^{-1}$
(Figure 2), and no effect on biomass concentration. Therefore, it was fixed at the central point (5). For other strains of $P$. rhodozyma, $\mathrm{pH} 5$ was appropriate for cell growth and the production of carotenoids (Liu; $\mathrm{Wu}, 2007$; Ni et al., 2007), similar to the choice in this work.

The results of the $2_{\mathrm{IV}}{ }^{6-2}$ fractional factorial design show that the presence of yeast extract up to $1 \mathrm{~g} \mathrm{~L}^{-1}$ was not significant for the production of carotenoids. The use of yeast extract up to $1 \mathrm{~g} \mathrm{~L}^{-1}$ was studied separately $\left(0,0.5\right.$ and $\left.1 \mathrm{~g} \mathrm{~L}^{-1}\right)$ and, according to Table 3, also showed no significant difference in the production of carotenoids. Therefore, the RPW medium for carotenoids production used in these experiments could be used as a source of nitrogen and other nutrients associated with other components of the medium. The absence of yeast extract reduces the costs of the production medium. Thus, the yeast extract was removed from the production environment for study in the CCD $2^{4}$.

\section{Central composite design (CCD)}

The maximization of carotenoid production was carried out using a $2^{4} \mathrm{CCD}$ with four variables selected from the fractional factorial design. The ranges of the concentrations of malt extract, peptone and sucrose (Table 1 and Table 4) were expanded due to the increase in all studied responses. The concentration range of the RPW was decreased according to the results for the volumetric production of carotenoids. The initial $\mathrm{pH}$ of the culture medium was fixed at a central point (5.0), and yeast extract was discarded.

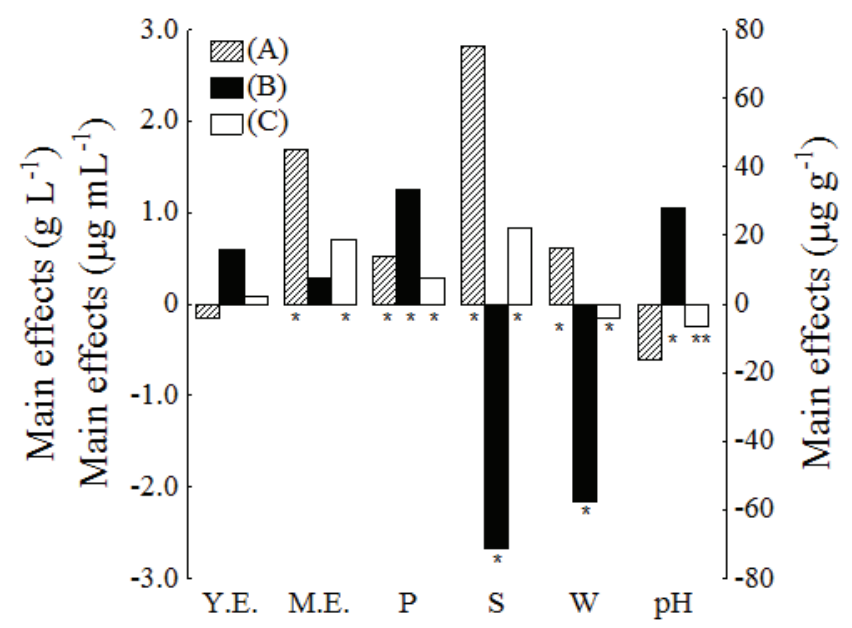

Figure 2: Main effects of carotenoids production for the responses biomass concentration (g $\left.\mathrm{L}^{-1}\right)(\mathrm{A})$, specific production $\left(\mu \mathrm{g} \mathrm{g}^{-1}\right)(\mathrm{B})$ and volumetric production of carotenoids $\left(\mu \mathrm{g} \mathrm{mL}^{-1}\right)(\mathrm{C})$. Y.E.: yeast extract, M.E.: malt extract, $\mathrm{P}$ : peptone, $\mathrm{S}$ : sucrose and $\mathrm{W}$ : rice parboiling wastewater $(* \mathrm{p}<0.1 * * \mathrm{p}<0.15)$. 
Table 3: ANOVA and Tukey's test for the different yeast extract concentrations $(n=3)$.

\begin{tabular}{cccc}
\hline $\mathrm{YE}(\mathrm{g} / \mathrm{L})$ & $\mathrm{Y}_{1}\left(\mathrm{~g} \mathrm{~L}^{-1}\right)$ & $\mathrm{Y}_{2}\left(\mu \mathrm{g} \mathrm{g}^{-1}\right)$ & $\mathrm{Y}_{3}\left(\mu \mathrm{g} \mathrm{mL}^{-1}\right)$ \\
\hline 0 & $9.3 \pm 0.1^{\mathrm{a}}$ & $359.5 \pm 23.1^{\mathrm{a}}$ & $3.0 \pm 0.1^{\mathrm{a}}$ \\
0.5 & $8.2 \pm 0.3^{\mathrm{b}}$ & $385.9 \pm 5.6^{\mathrm{a}}$ & $3.0 \pm 0.1^{\mathrm{a}}$ \\
1 & $8.8 \pm 0.2^{\mathrm{ab}}$ & $345.4 \pm 31.4^{\mathrm{a}}$ & $2.8 \pm 0.2^{\mathrm{a}}$ \\
\hline
\end{tabular}

Means with different superscript letters within the same column are significantly different $(\mathrm{p}<0.05)$. YE [yeast extract $\left.\left(\mathrm{g} \mathrm{L}^{-1}\right)\right]$; $\mathrm{Y}_{1}$ [biomass $\left.\left(\mathrm{g} \mathrm{L}^{-1}\right)\right] ; \mathrm{Y}_{2}\left[\right.$ specific carotenoids $\left.\left(\mu \mathrm{g} \mathrm{g}^{-1}\right)\right] ; \mathrm{Y}_{3}$ [volumetric carotenoids $\left(\mu \mathrm{g} \mathrm{mL} \mathrm{m}^{-1}\right)$ ].

Table 4 show the results obtained in the $2^{4} \mathrm{CCD}$ for the maximum responses (biomass concentration and specific and volumetric concentrations of carotenoids), the residual sucrose and the relative deviations from the predicted model (Equation 2). The biomass ranged from $6.7 \mathrm{~g} \mathrm{~L}^{-1}$ (trial 9 in $120 \mathrm{~h}$ ) to $10.9 \mathrm{~g} \mathrm{~L}^{-1}$ (trial 14 in $168 \mathrm{~h}$ ).
The C:N ratio varied from 5.8 (trial 4) to 15.1 (trial 13), promoting the production of carotenoids in all compositions of the culture medium (trial 1 to 19). The specific production ranged from $312.2 \mu \mathrm{g} \mathrm{g}^{-1}$ (trial 7 in $72 \mathrm{~h}$ ) to $628.8 \mu \mathrm{g} \mathrm{g}^{-1}$ (trial 2 in $144 \mathrm{~h}$ ), and the volumetric production ranged from $2.3 \mu \mathrm{g} \mathrm{mL}^{-1}$ (trial 16 in $144 \mathrm{~h}$ ) to $5.3 \mu \mathrm{g} \mathrm{mL}^{-1}$ (trial 2 in $144 \mathrm{~h}$ ), with an increase occurring in all responses relative to the $2_{\mathrm{IV}}{ }^{6-2}$ fractional factorial design. The residual sucrose varied from $3.1 \%$ (trial 17 ) to $20.1 \%$ (trial 8).

ANOVA (data not shown) for the volumetric production of carotenoids showed that the pure error was very low (0.02), indicating a good reproducibility of the experimental data. The Fisher F-test is a ratio of the means square from regression of the means square from the real error (Rodrigues; Iemma, 2012). It shows that the model is predictive, as the calculated F-value (10) was three times higher than the tabulated F-value $\left(\mathrm{F}_{0.95 ; 6 ; 12}=3.0\right)$ at the $5 \%$ level, and that the regression coefficient $(0.82)$ is good enough (Haaland, 1989). Therefore, the model (Equation 2)

Table 4: $2^{4}$ Central Composite Design with real values of the variables $\left(\mathrm{X}_{\mathrm{n}}\right), \mathrm{C}: \mathrm{N}$ ratio and the maximum responses $\left(\mathrm{Y}_{\mathrm{n}}\right)$ of biomass concentration, specific production of carotenoids, volumetric production of carotenoids and relative desviation (\%) and residual sucrose (\%).

\begin{tabular}{crrrrrrrrrr}
\hline Trial & \multicolumn{1}{c}{$\mathrm{X}_{1}$} & \multicolumn{1}{c}{$\mathrm{X}_{2}$} & $\mathrm{X}_{3}$ & \multicolumn{1}{c}{$\mathrm{X}_{4}$} & $\mathrm{C}: \mathrm{N}$ & \multicolumn{1}{c}{$\mathrm{Y}_{1}$} & $\mathrm{Y}_{2}$ & $\mathrm{Y}_{3}$ & $\mathrm{Y}_{4}$ & $\mathrm{Y}_{5}$ \\
\hline 1 & 8.75 & 8.75 & 15 & 87.5 & 8.2 & 7.6 & 504.0 & 3.4 & 2.9 & 6.2 \\
2 & 16.25 & 8.75 & 15 & 87.5 & 7.6 & 9.7 & 628.8 & 5.3 & -1.9 & 7.8 \\
3 & 8.75 & 16.25 & 15 & 87.5 & 6.0 & 7.1 & 370.5 & 2.4 & -4.2 & 6.4 \\
4 & 16.25 & 16.25 & 15 & 87.5 & 5.8 & 8.6 & 576.5 & 5.0 & 2.0 & 17.3 \\
5 & 8.75 & 8.75 & 35 & 87.5 & 15 & 10.1 & 336.0 & 3.1 & 0.0 & 4.4 \\
6 & 16.25 & 8.75 & 35 & 87.5 & 13.9 & 10.0 & 502.4 & 5.0 & 13.6 & 18.4 \\
7 & 8.75 & 16.25 & 35 & 87.5 & 9.8 & 9.3 & 312.2 & 2.7 & 7.4 & 11.9 \\
8 & 16.25 & 16.25 & 35 & 87.5 & 9.5 & 9.4 & 530.1 & 3.9 & 0.0 & 20.1 \\
9 & 8.75 & 8.75 & 15 & 162.5 & 8.3 & 6.7 & 593.6 & 4.0 & 7.5 & 5.0 \\
10 & 16.25 & 8.75 & 15 & 162.5 & 7.8 & 7.2 & 540.8 & 3.9 & 0.0 & 4.6 \\
11 & 8.75 & 16.25 & 15 & 162.5 & 6.1 & 7.3 & 420.0 & 3.0 & 16.7 & 12.9 \\
12 & 16.25 & 16.25 & 15 & 162.5 & 5.9 & 8.4 & 491.6 & 3.9 & 15.4 & 6.3 \\
13 & 8.75 & 8.75 & 35 & 162.5 & 15.1 & 10.4 & 379.5 & 3.6 & 2.8 & 4.0 \\
14 & 16.25 & 8.75 & 35 & 162.5 & 14.1 & 10.9 & 355.3 & 2.9 & 0.0 & 11.9 \\
15 & 8.75 & 16.25 & 35 & 162.5 & 9.9 & 9.0 & 485.3 & 3.5 & 11.4 & 8.2 \\
16 & 16.25 & 16.25 & 35 & 162.5 & 9.5 & 7.9 & 399.6 & 2.3 & 0.0 & 9.2 \\
17 & 12.50 & 12.50 & 25 & 125 & 9.1 & 8.6 & 402.6 & 2.6 & -20.7 & 3.1 \\
18 & 12.50 & 12.50 & 25 & 125 & 9.1 & 8.0 & 424.2 & 2.7 & -29.6 & 5.4 \\
19 & 12.50 & 12.50 & 25 & 125 & 9.1 & 9.6 & 351.9 & 2.8 & -25.0 & 3.2 \\
\hline $\mathrm{X}$
\end{tabular}

$\mathrm{X}_{1}\left[\right.$ malt extract $\left.\left(\mathrm{g} \mathrm{L}^{-1}\right)\right] ; \mathrm{X}_{2}$ [peptone $\left.\left(\mathrm{g} \mathrm{L}^{-1}\right)\right] ; \mathrm{X}_{3}$ [sucrose $\left.(\mathrm{g} / \mathrm{L})\right] ; \mathrm{X}_{4}\left[\mathrm{RPW}\left(\mathrm{g} \mathrm{L}^{-1}\right)\right] ; \mathrm{Y}_{1}\left[\right.$ biomass $\left.\left(\mathrm{g} \mathrm{L}^{-1}\right)\right] ; \mathrm{Y}_{2}$ [specific carotenoids $\left.\left(\mu \mathrm{g} \mathrm{g}^{-1}\right)\right] ; \mathrm{Y}_{3}$ [volumetric carotenoids $\left.\left(\mu \mathrm{g} \mathrm{mL}^{-1}\right)\right] ; \mathrm{Y}_{4}$ [Relative desviation (\%)]; $\mathrm{Y}_{5}$ [Residual Sucrose (\%)]. 
to represent the relationship between the responses and the significant variables was used to generate the response surfaces (Figure 3 ). The relative deviations between the experimental and predicted results based on the model were less than $15 \%$ in most trials (Table 3 ), showing that Equation 2 predicts the behavior of volumetric production.

Volumetric carotenoids $\left(\mu \mathrm{g} \mathrm{mL}^{-1}\right)=3.49+0.41 \mathrm{X}_{1}$ $0.28 X_{2}-0.24 X_{3}-0.23 X_{4}-0.24 X_{1} X_{3}-0.54 X_{1} X_{4}$

Figure 3 shows the effects of the concentrations of malt extract, peptone, sucrose and RPW on the volumetric production of carotenoids. When the peptone concentration was low and the malt extract concentration high, carotenoids production remained at approximately $3.8-4.1 \mu \mathrm{g} \mathrm{mL}^{-1}$ (Figure $3 \mathrm{~A})$. When the malt extract concentration was high and the sucrose concentration low (Figure 3B) or when the RPW concentration was low and the malt extract concentration high, the volumetric production of carotenoids was above $4.3 \mu \mathrm{g} \mathrm{mL}^{-1}$ (Figure $3 \mathrm{C}$ ). Figures $3 \mathrm{D}, 3 \mathrm{E}$ and $3 \mathrm{~F}$ show that the volumetric production of carotenoids was from 3.9$4.0 \mu \mathrm{g} \mathrm{mL}^{-1}$ when the concentrations of peptone and sucrose, peptone and RPW, and sucrose and RPW, respectively, in the culture medium were low.

The surfaces indicate a high volumetric production of carotenoids by P. rhodozyma NRRL Y-17268 using a culture medium containing $16.25 \mathrm{~g} \mathrm{~L}^{-1}$ malt extract, $8.75 \mathrm{~g} \mathrm{~L}^{-1}$ peptone, $15 \mathrm{~g} \mathrm{~L}^{-1}$ sucrose and $87.5 \mathrm{~g} \mathrm{~L}^{-1}$ rice parboiling wastewater (trial 2 in Table 4), with a $\mathrm{C}: \mathrm{N}$ ratio of 7.6. Under these conditions, the relative deviation provided by the model was less than $5 \%$. Figure 4 presents the kinetics of carotenoid production in
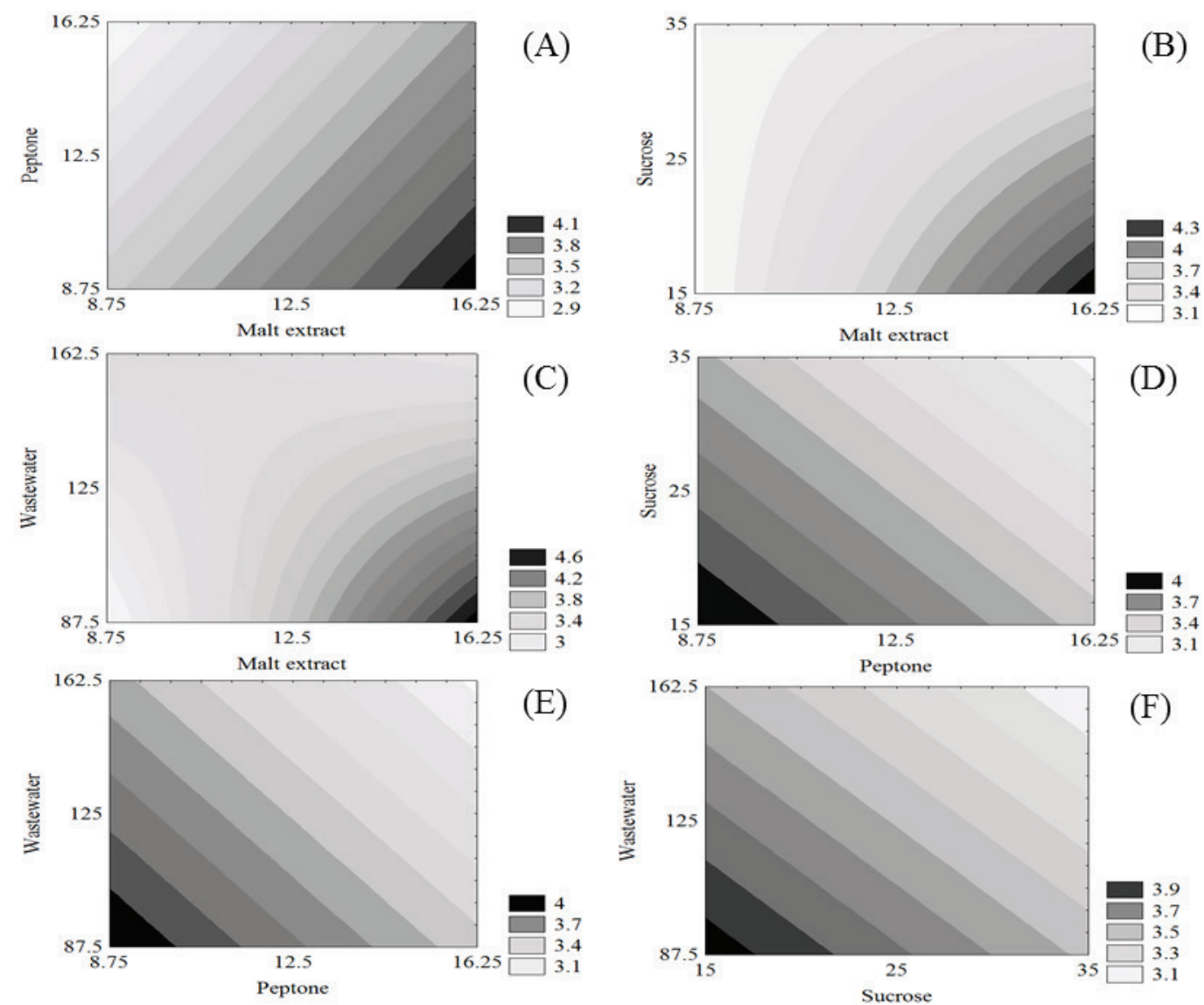

Figure 3: Contour diagrams for volumetric carotenoids production $\left(\mu \mathrm{g} \mathrm{mL}^{-1}\right)$ as a function of malt extract and peptone concentration (A), malt extract $\left(\mathrm{g} \mathrm{L}^{-1}\right)$ and sucrose $\left(\mathrm{g} \mathrm{L}^{-1}\right)(\mathrm{B})$, malt extract $\left(\mathrm{g} \mathrm{L}^{-1}\right)$ and rice parboiling wastewater $\left(\mathrm{g} \mathrm{L}^{-1}\right)$, peptone $\left(\mathrm{g} \mathrm{L}^{-1}\right)$ and sucrose $\left(\mathrm{g} \mathrm{L}^{-1}\right)$ and rice parboiling wastewater $\left(\mathrm{g} \mathrm{L}^{-1}\right)(\mathrm{E})$, sucrose $\left(\mathrm{g} \mathrm{L}^{-1}\right)$ and rice parboiling wastewater $\left(\mathrm{g} \mathrm{L}^{-1}\right)(\mathrm{F})$. 


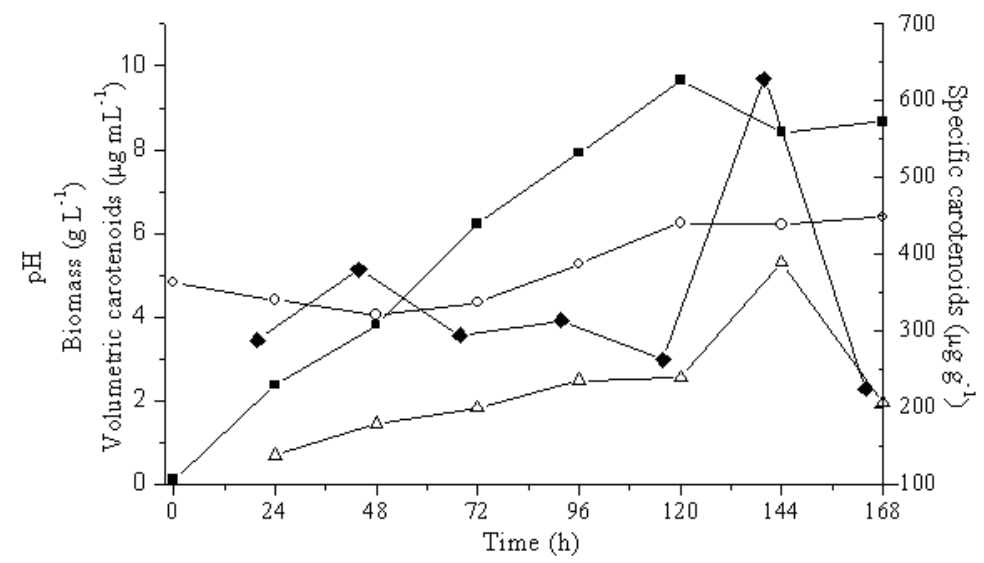

Figure 4: Bioproduction of carotenoids by P. rhodozyma NRRL Y-17268 using culture medium with $16.25 \mathrm{~g} \mathrm{~L}^{-1} \mathrm{malt}^{-1}$ extract, $8.75 \mathrm{~g} \mathrm{~L}^{-1}$ peptone, $15 \mathrm{~g} \mathrm{~L}^{-1}$ sucrose and $87.5 \mathrm{~g} \mathrm{~L}^{-1}$ rice parboiling wastewater (trial 2 in Table 3 ) at $25^{\circ} \mathrm{C}$ and $150 \mathrm{rpm}$. $\square$ biomass, $\circ \mathrm{pH}, \Delta$ volumetric carotenoids, specific carotenoids.

this condition. The volumetric and specific carotenoid production increased up to $144 \mathrm{~h}$, reaching $5.3 \mu \mathrm{g} \mathrm{mL} \mathrm{m}^{-1}$ and $628.8 \mu \mathrm{g} \mathrm{g}^{-1}$, respectively. The biomass concentration reached a maximum of $9.7 \mathrm{~g} \mathrm{~L}^{-1}$ after $120 \mathrm{~h}$, as carotenoid synthesis is partially associated with cell growth and the production occurs even after the cell death phase of the microorganism (Vustin; Belykh; Kishilova, 2004, Liu; $\mathrm{Wu}, 2007)$. The $\mathrm{pH}$ shows the characteristic behavior of this yeast (Vustin; Belykh; Kishilova, 2004), with an initial fall up to $48 \mathrm{~h}(5-4)$ followed by an increase and a constant period.

It was not possible to establish a significant predictive model for specific carotenoids production and biomass concentration. The volumetric production of carotenoids was maximized by the CCD study including RPW in the culture medium as a substrate, adding value to the agroindustrial effluent. The volumetric production of carotenoids increased by approximately $75 \%$, reaching $5.3 \mu \mathrm{g} \mathrm{mL}^{-1}$ in $144 \mathrm{~h}$ (trial 2 in Table 3), in relation to the highest value obtained in the fractional factorial design, $3.1 \mu \mathrm{g} \mathrm{mL}^{-1}$ in $168 \mathrm{~h}$ (trial 15), using the experimental design methodology and with a reduced process time.

In the present study, the specific production of carotenoids $\left(628.8 \mu \mathrm{g} \mathrm{g}^{-1}\right)$ and the volumetric production of carotenoids $\left(5.3 \mu \mathrm{g} \mathrm{mL}^{-1}\right)$ were higher than those found in the literature for different culture mediums and various strains of $P$. rhodozyma. The carotenoids production by $P$. rhodozyma 67-385 was reported to be $310 \mu \mathrm{g} \mathrm{g}^{-1}$ (An; Cho; Johnson, 1999). P. rhodozyma NRRL Y-10921 and NRRL Y-10922 reached $1.6 \mu \mathrm{g} \mathrm{mL}^{-1}$ and $3.0 \mu \mathrm{g} \mathrm{mL}^{-1}$, respectively
(Vázquez; Santos; Parajó, 1997), and P. rhodozyma AS 2.1557 achieved $3.5 \mu \mathrm{g} \mathrm{mL}^{-1}$ (Wang; Yu; Zhou, 2006). Using the same microorganism as in this work, Vázquez, Santos and Parajó (1997) reached $3.6 \mu \mathrm{g} \mathrm{mL}^{-1}$, and Silva et al. (2012) obtained $1.7 \mu \mathrm{g} \mathrm{mL}^{-1}$.

\section{CONCLUSIONS}

The use of rice parboiling wastewater as an alternative substrate for the production of carotenoids by P. rhodozyma NRRL Y-17268 was observed in this work. The conditions of the medium culture established for the maximization of the volumetric production of carotenoids were $16.25 \mathrm{~g} \mathrm{~L}^{-1}$ malt extract, $8.75 \mathrm{~g} \mathrm{~L}^{-1}$ peptone, $15 \mathrm{~g}$ $\mathrm{L}^{-1}$ sucrose, $87.5 \mathrm{~g} \mathrm{~L}^{-1}$ rice parboiling wastewater, initial $\mathrm{pH}$ of $5,25^{\circ} \mathrm{C}$, and $150 \mathrm{rpm}$ during $144 \mathrm{~h}$ of culture. Under these conditions, the utilization of rice parboiling wastewater to replace the yeast extract added value to the agroindustrial effluent, reaching $5.3 \mu \mathrm{g} \mathrm{mL}^{-1}\left(628.8 \mu \mathrm{g} \mathrm{g}^{-1}\right)$ of carotenoids in $144 \mathrm{~h}$.

\section{ACKNOWLEDGEMENTS}

The authors thank the research funding agencies Fapergs, Capes and $\mathrm{CNPq}$, for the financial support received for this work.

\section{REFERENCES}

AN, G.; CHO, M.; JOHNSON, E. A. Monocyclic carotenoid biosynthetic pathway in the yeast Phaffia rhodozyma (Xanthophyllomyces dendrorhous). Journal of Bioscience and Bioengineering. 88(2):189-193, 1999. 
AOAC- Association of official analytical communities. Official Methods of Analysis. 17 ed. Arlington: AOAC International, 2000.

CABRAL, M. M. S. et al. Carotenoids production from a newly isolated Sporidiobolus pararoseus strain by submerged fermentation. European Food Research and Technology. 233:159-166, 2011.

DOMÍNGUEZ-BOCANEGRA, A. R; PONCENOYOLA, T.; TORRES-MUÑOZ, J. A. Astaxanthin production by Phaffia rhodozyma and Haematococcus pluvialis: a comparative study. Applied Microbiology and Biotechnology. 75:783-791, 2007.

FONSECA, R. A. S. et al. Different cell disruption methods for astaxanthin recovery by Phaffia rhodozyma. African Journal of Biotechnology. 10(7):1165-1171, 2011.

GU, Z. et al. Optimization of carotenoids extraction from Rhodotobacter sphaeroides. LWT - Food Science and Technology. 41:1082-1088, 2008.

HAALAND P.D. (Ed.), Experimental Design in Biotechnology. Marcel Dekker Inc., New York, 1989.

IP, P.; CHEN, F. Production of astaxanthin by the green microalga Chlorella zofingiensis in the dark. Process Biochemistry. 40:733-738, 2005.

KUSDIYANTINI, E. et al. Growth kinetics and astaxanthin production of Phaffia rhodozyma on glycerol as a carbon source during batch fermentation. Biotechnology Letters. 20(10):929-934, 1998.

LIU, Y. S.; WU, J. Y. Optimization of cell growth and carotenoid production of Xanthophyllomyces dendrorhous trough statistical experiment design. Biochemical Engineering Journal. 36(2):182-189, 2007.

MICHELON, M. et al. Extraction of carotenoids from Phaffia rhodozyma: a comparison between different techniques of cell disruption. Food Science and Biotechnology. 21(1):1-8, 2012.

MILLER, G. L. Use of dinitrosalicylic acid reagent for determination of reducing sugar. Analytical Chemistry. 31:426-428, 1959.
NI, H. et al. Optimization of acidic extraction of astaxanthin from Phaffia rhodozyma. Journal of Zhejiang University - Science B, 9(1):51-59, 2008.

Studies on optimization of nitrogen

sources for astaxanthin production by Phaffia rhodozyma. Journal of Zhejiang University - Science B. 8(5):365-370, 2007.

QUEIROZ, M. I. et al. The kinetics of the removal of nitrogen and organic matter from parboiled rice effluent by cyanobacteria in a stirred batch reactor. Bioresource Technology, 98(11):2163-2169, 2007.

RODRÍGUEZ-SÁIZ, M.; FUENTE, J. L.; BARREDO, J. L. Xanthophyllomyces dendrorhous for the industrial production of astaxanthin. Applied Microbiology and Biotechnology. 88(3):645-658, 2010.

RODRIGUES, M. I.; IEMMA, A. F. Experimental design and process optimization. Casa de Espírito Amigo Fraternidade Fé e Amor. 2nd. Campinas, São Paulo, 2012. 352 p.

SILVA, C. M. et al. Carotenoid production by Phaffia rhodozyma using raw glycerol as an additional carbon source. International Journal of Food Engineering. 8(4):1-15, 2012.

VALDUGA, E. et al. Evaluation of aeration and substrate concentration on the production of carotenoids by Sporidiobolus salmonicolor (CBS 2636) in bioreactor. European Food Research and Technology 232:453-462, 2011.

VÁZQUEZ, M.; SANTOS, V.; PARAJÓ, J. C. Effect of the carbon source on the carotenoid profiles of Phaffia rhodozyma strains. Journal of Industrial Microbiology \& Biotechnology. 19:263-268, 1997.

VENIL, C.K.; ZAKARIA, Z.A.; AHMAD, W.A. Review: bacterial pigments and their applications. Process Biochemistry. 48:1065-1079, 2013.

VUSTIN, M. M.; BELYKH, E. N.; KISHILOVA, S. A. Relationship between astaxanthin production and intensity of anabolic processes in the yeast Phaffia rhodozyma. Microbiology. 73(6):751-757, 2004. 
WANG, W.; YU, L.; ZHOU, P. Effects of different fungal elicitors on growth, total carotenoids and astaxanthin formation by Xanthophyllomyces

dendrorhous. Bioresource Technology. 97(1):26-31, 2006.
ZEPKA, L. Q. et al. Production and biochemical profile of the microalgae Aphanothece microscopiac Nägeli submitted to different drying conditions. Chemical Engineering and Processing: Process Intensification. 47(8):1305-1310, 2008.

Ciênc. Agrotec., Lavras, v. 39, n. 4, p. 401-410, jul./ago., 2015 